\title{
Sustainable recycling technologies for Solar PV off-grid system
}

\author{
Bhavesh Uppal, Adish Tamboli, Nandan Wubhayavedantapuram
}

\author{
Global Production Engineering, Technical University Berlin, \\ Department Assembly Technology and Factory Management, \\ Pascalstr. 8-9, D-10587, Berlin, Germany \\ Email:b.uppal@campus.tu-berlin.de,adishtambo@gmail.com,wsnandan@gmail.com
}

\begin{abstract}
Policy makers throughout the world have accepted climate change as a repercussion of fossil fuel exploitation. This has led the governments to integrate renewable energy streams in their national energy mix. PV off-grid Systems have been at the forefront of this transition because of their permanently increasing efficiency and cost effectiveness. These systems are expected to produce large amount of different waste streams at the end of their lifetime. It is important that these waste streams should be recycled because of the lack of available resources. Our study found that separate researches have been carried out to increase the efficiencies of recycling of individual PV system components but there is a lack of a comprehensive methodical research which details efficient and sustainable recycling processes for the entire PV off-grid system. This paper reviews the current and future recycling technologies for PV off-grid systems and presents a scheme of the most sustainable recycling technologies which have the potential for adoption. Full Recovery End-of-Life Photovoltaic (FRELP) recycling technology can offer opportunities to sustainably recycle crystalline silicon PV modules. Electro-hydrometallurgical process \& Vacuum technologies can be used for recovering lead from lead acid batteries with a high recovery rate. The metals in the WEEE can be recycled by using a combination of biometallurgical technology, vacuum metallurgical technology and other advanced metallurgical technologies (utrasonical, mechano-chemical technology) while the plastic components can be effectively recycled without separation by using compatibilizers. All these advanced technologies when used in combination with each other provide sustainable recycling options for growing PV off-grid systems waste. These promising technologies still need further improvement and require proper integration techniques before implementation.
\end{abstract}

Keywords: Recycling, PV off-grid system, Sustainability, Solar panels, Lead acid battery, WEEE

\section{Introduction}

Photovoltaic systems are becoming increasingly affordable for producing electricity. The total installed capacity of PV systems is estimated around 222 GW at the end of 2015 [1]. Crystalline-silicon PV technology dominates the market with $85-90 \%$ of the share because of its low cost and high efficiency [2]. Off-grid PV systems can be used for both domestic and low energy non- 
domestic purpose. Globally around 6 million homes were electrified with offgrid PV systems till 2015 [3]. These systems generally consist of PV module, lead acid battery and other electrical and electronic equipments. Many photovoltaic systems are at their end phase of life cycle and a lot of e-waste will be generated in the coming years. The average lifetime of crystalline silicon photovoltaic module is about 25-30 years. The global cumulative PV panel waste is expected to reach 60 million tons by the end of 2050 [1]. Average life of lead acid battery depends on its usage cycle. For any off-grid PV system till the end-of-life of PV module, generally 2-3 lead acid battery replacements are required. Inverters, charge controllers etc. if installed, operated and maintained properly may run through till the end-of-life of PV module. Our study found that separate researches have been carried out to increase efficiency of recycling of different PV system components. But there is no concrete methodical research available which will explain efficient and sustainable recycling processes for the entire PV off-grid system. In developing countries where off-grid system installations are increasing at a high rate, there is no industrial network available for recycling of PV off-grid system components in efficient and environmental friendly way. The specific combination of all sustainable and efficient recycling techniques for major off-grid system components is needed to analyze recycling efficiency and environmental impacts of whole system. This paper first evaluates possible recycling techniques for recovery of materials from major components of PV off-grid solar system. After the evaluation of technologies, a framework was developed which focused on the most efficient and sustainable processes for recycling of major PV off-grid system components.

\section{Literature review}

Extensive research has been carried out on recycling PV modules as first generation of PV modules are in their end-of-life phase. Latunussa et al. [4] mentioned that recycling of silicon PV modules can be carried out by physical/chemical treatment or combination of both. In their research, they focused on innovative process called FRELP for recycling of Si PV module. Granata et al. [5] studied in detail about various physical treatments for recycling of Si and CdTe photovoltaic modules. Their analysis presented that recycling by physical treatment with two blade rotors crushing followed by hammer crushing and eventually by a thermal treatment was the best option aiming to a direct recovery of glass. Ostrowski et al. [6] researched on various chemical treatment of recycling for crystalline silicon PV module. In their research, a series of etching processes were carried which includes etching of electric connectors, anti-reflective coating and n-p junction. Kang et al. [2] presented that $86 \%$ silicon can be recovered from any $\mathrm{Si}-\mathrm{PV}$ module through most efficient 
recycling techniques. Ashfaq et al. [7] analyzed that about $90 \%$ of the materials recovered from solar panels can be recycled into useful products.

Many developments are being carried out in recycling lead acid batteries by emphasizing new technological methods. Espinosa et al. [8] studied about the current methods for battery recycling like separation of components, pyrometallurgy and hydrometallurgy. Their research presented about the different technological process available for recycling the batteries. Jolly et al. [9] studied about the process of recycling lead acid batteries by separation process i.e. battery breaking \& smelting for production of lead and polypropylene. Blanpain et al. [10] analysed the advantages and drawbacks of the different recycling technologies. Ferracin et al. [11] studied the lead recovery from lead acid batteries using an electro-hydrometallurgical process. Lin et al. [12] conducted experimental analysis of vacuum process for recycling of waste lead storage battery. Zhang et al. [13] studied about the practices in secondary lead recycling technologies (Electrowinning) and development of sustainable greener recycling methods, such as Paste-to-Paste recycling and hydrogen-lead oxide fuel cell method. Chen et al. [14] analysed the environmental impacts of lead acid batteries. Their research suggested the environmental risk assessment methodology for the lead acid batteries. Zabaniotou et al. [15] studied about the application of modern recycling technologies in accordance to the European and Greek legislation aiming at the recovery of lead; polypropylene and sulphuric acid from spend lead acid batteries.

Research has also been carried out to understand the amount of E-waste or WEEE being produced every year, the components of E-waste, the methods to recycle them and the problems associated with recycling E-waste. Widmer et al. [16] presented the global outlook of the problems associated with handling large amounts of E-waste. Their research reviewed the legal frameworks of different countries to tackle e-waste management issue. Ongondo et al. [17] reviewed the global WEEE in the year 2010 in different countries. Their paper discussed on the common priority areas for WEEE across the globe and the future WEEE generation, treatment, prevention and regulation activity. Zhang et al. [18] reviewed the latest recycling technologies to extract metals from WEEE. They elaborated on the shortfalls of each technology from technical and environmental perspective and discussed the future development of recycling technologies for extraction of metals from WEEE. Makenji et al. [19] examined in detail the mechanical recycling of plastics from WEEE. The effectiveness of mechanical separation techniques like floating, hydro-cyclone, air tabling, near infra-red and electrostatic sorting for recycling plastics from WEEE was presented in detail. Vazquez et al. [20] studied the effect of the use of campatibilizers on the recycling of plastic waste from WEEE. Their study 
suggested an improvement in the mechanical properties of preliminary WEEE plastics through use of campatibilizers. Chi et al. [21] reviewed low cost informal practices of e-waste recycling with a special focus on China and the problems associated with informal e-waste recycling techniques. Huang et al. [22] studied the health hazards for residents around e-waste recycling sites. Their research suggested that the incremental lifetime cancer risk of five carcinogenic metals $\mathrm{Cr}, \mathrm{Co}, \mathrm{Ni}, \mathrm{As}$ and $\mathrm{Cd}$ was higher than acceptable range.

\section{Method}

Selection and classification of the research methods were divided into three steps: The first step was to conduct a literature review by a comprehensive search on Sciencedirect and online web database with keywords "recycle" and "technology" and "crystalline silicon module" and "WEEE" and "Lead acid battery". The abstract of the relevant papers were studied and the literatures were classified depending on the component of recycling. In second step, Recycling technologies were studied for crystalline silicon PV modules, lead acid batteries and WEEE. These technologies were evaluated based on sustainability in terms of economic, environmental and social perspectives. In the last step, the most promising technologies that address efficient and sustainable recycling ways were selected and presented in a scheme. Finally, future recommendations for improvements were suggested.

\section{Photovoltaic Module}

Crystalline silicon-type PV module consists of glass, aluminum frame, EVA coating, solar cells and terminal box [5]. Following table explains various physical /chemical treatments or their combination for recovery of various materials such as aluminum, glass, silicon, silver, copper, Ethylene vinyl acetate, plastics etc.

Table 1: Various Processes developed for Recycling of Crystalline PV panels [4] 
EVA removed by dissolution in organic solvents

Pyrolysis process of EVA at different heating rates under different oxidizing atmosphere

Thermal and chemical process applied to a large sample of module

Two-step heating process of EVA followed by chemical processes with acid and alkali

Dissolution of EVA by organic solvents and treatment of the PV cell by chemical etching

Two processes based on two blade rotors crushing followed by thermal treatment and two blade rotors crushing followed by hammer crushing

FRELP (Full Recovery End Life Photovoltaic
Silicon cell can be separated without any damage from single cell module

The pyrolysis behavior of EVA is strongly influenced by the content of acetate in the EVA

The process achieved a separation yield of about $76 \%$ of the cells

$85 \%$ of copper and $62 \%$ of the silicon were separated The process allowed to recover up to $86 \%$ of the silicon with very high purity

Recover $80-85 \%$ of the glass

Up to $95 \%$ recovery of silicon

\section{Full Recovery End Life Photovoltaic (FRELP):}

A recent research project has been financed by the EU and in partnership with PV Cycle Italy, titled "Full Recovery End of Life Photovoltaic project-FRELP", aiming at maximizing the recycling of the different materials of a silicon PV panel. The FRELP project had the objective of developing an innovative recycling process (successively defined as 'FRELP process) for Crystalline $\mathrm{Si}$ PV waste aiming at maximizing the recovery of all the material. This method implies combination of various methods with innovative approach (explained in table 1) to recover solar panel component materials [2]. At first all waste PV panels are collected at most optimized location by consideration of transport. Transport is generally ignored in recycling calculations. FRELP aims to choose optimized location for recycling, collecting and landfill sites. Automated system with robots is utilized to dismantle PV waste panel. In this phase, aluminum frame, cables, photovoltaic cell, glass, plastic parts are separated. Glass is separated by mechanical detachment with prior treatment by short and medium 
wave infra-red to PV panels. By using sieving and optical based separation system, glass is separated from impurities. Incineration process is used for recovery of PV cell materials such as aluminum and silicon. Output of incineration process is treated with acid $\left(\mathrm{HNO}_{3}\right)$ leaching process. This process separates metal and silicon from incineration ash. With leaching process, up to $95 \%$ of silicon can be recovered. Lastly, electrolysis is used to recover silver and copper from leaching process solution and waste sludge is collected to landfill it [2].

\section{Lead Acid Batteries}

Lead Acid Batteries (LABs) are the most commonly used storage unit in the off-grid solar PV systems due to low cost and high energy density. About 97\% of all lead-acid batteries are recycled today and have highest recycling rate compared to other consumer products [23]. The recycling of LABs includes recovery of valuable materials like lead, polypropylene, sodium sulphate crystals and lead pastes and helps to reduce the environmental effects [12]. Generally, discarded LABs are the major resource of secondary lead; more than $85 \%$ in the total amount of secondary lead is from LABs [10]. For recycling purpose, analyses of major components of the LABs are considered. The current recycling practices are considered for evaluation of the recyclability of LABs in off-grid solar PV systems. The recyclability rate of the batteries depends on the type of the process used. In addition, environmental aspects are also considered to address the sustainable recycling techniques. The methods are as follows:

(1) Pyrometallurgical Process: Pyrometallurgical process is the most common method that is currently in practice for recycling of LABs. The LABs are smelted in the furnace to produce antimonial lead bullion and soda slags or mattes. Many developments were done in this process which includes the utilization of different type of furnaces and preheating equipment [13]. Recent technological methods in the smelting process of LAB's are QSL process, Isasmelt Paste Smelting process, Kivcet method, Kaldo smelting process and Rotary or Reverberatory furnace smelting. The recyclability rate of the lead acid battery by Pyrometallurgical method is $90 \%$. Although, the process is efficient it has severe environmental effects due to $\mathrm{SO}_{2}$ emissions and lead emissions from fuming at elevated temperatures [12].

(2) Electro-hydrometallurgical Process: In recent years, considering the environmental impact by recycling of LABs by pyrometallurgy process, a cleaner technology, electro-hydrometallurgical technique was developed. The process employs alternative techniques instead of smelting like dissolving the 
lead sludge in acidic or basic media. In this process, the lead acid batteries are crushed and sulphuric acid, plastic, metallic and non-metallic portions are separated. The plastic components are reprocessed again and the metallic components are re-melted. The battery sludge which contains major lead compounds undergoes desulphurization process. After desulphurization process, the leaching process is carried out using a suitable electrolyte to solubilize the lead compounds remaining in the residue. Finally, the lead is then recovered from solution by electrowinning technique using insoluble anodes [11].

(3) Vacuum Process: One of the recent developments in LABs recycling includes the utilization of vacuum technologies. The process includes the separation of the LABs into 3 components: (1) Plastic shell and cover; (2) Lead grids, (3) Lead pastes [12]. Initially, the grids are melted under vacuum to generate lead bullions by separating the oxidized component of the lead. The lead bullion produced by this process is of high purity. The lead pastes are also reduced in vacuum to generate lead bullion. The plastic components are recycled using pyrolysis process to generate pyrolysis oil and pyrolysis gas. As per the experimental research carried out by Deqiang et al., the lead bullion recovery ratio is $96.29 \%$ from grids and $98.98 \%$ from lead pastes. Thus, the vacuum technologies control emissions, metal loss and energy consumption.

\section{Waste Electrical and Electronic Equipment}

The WEEE of a typical off-grid PV system consists of but not limited to inverters, charge controllers, cables, switches, fuses, disconnects, MCB's, protection devices etc. Traditional WEEE disposing techniques include disassembly, classification, sorting and inefficient material extraction processes. For recycling metals, the traditional methods are incineration, separation through hydraulic bed shaking and acid leaching process. Incineration involves burning WEEE directly. It is a tedious process with different sub-processes and treatment techniques to extract the material. Through hydraulic bed shaking only crude copper particles can be extracted. However, this process generates a lot of waste water and residues. This can lead to secondary pollution if not handled carefully. The use of acids in acid leaching process of extraction can cause major environmental hazards and safety issues if not handled cautiously. These techniques do not provide value addition as precious metals are not extracted efficiently leading to large waste and bio hazards [18]. When different plastic wastes are accumulated together, it becomes economically unviable to separate them and recycle. This is because sorting techniques are labour intensive in their present state [19]. Recycling process can be considered successful only when it 
is easy to perform, is effective in recovering the maximum amount of material, is environmentally friendly and does not cause any health hazards. Over the years new and improved recycling technologies have been developed which encompass some of the above characteristics. Table 2 lists all kinds of improved technologies for recycling metals from WEEE along with their advantages and disadvantages with regards to environmental and technological aspect:

Table 2: Recycling technologies for WEEE [18]

\begin{tabular}{|c|c|c|c|c|}
\hline $\begin{array}{l}\text { Recycling } \\
\text { technology }\end{array}$ & $\begin{array}{l}\text { State of } \\
\text { recovery } \\
\text { metals }\end{array}$ & $\begin{array}{l}\text { Species and effect of } \\
\text { recovery metals }\end{array}$ & $\begin{array}{l}\text { Advantages of } \\
\text { environmental } \\
\text { and technological } \\
\text { aspect }\end{array}$ & $\begin{array}{l}\text { Disadvantages of } \\
\text { environmental and } \\
\text { technological aspect }\end{array}$ \\
\hline $\begin{array}{l}\text { Pyrometallur } \\
\text { gical } \\
\text { technology }\end{array}$ & $\begin{array}{l}\text { Pure solid } \\
\text { metals }\end{array}$ & $\begin{array}{l}\text { Almost all metals; } \\
\text { high recovery rate }\end{array}$ & $\begin{array}{l}\text { Totally-commercial; } \\
\text { owing } \\
\text { some dust chamber } \\
\text { and } \\
\text { exhaust gas treatment } \\
\text { plant }\end{array}$ & $\begin{array}{l}\text { High investment; fine } \\
\text { particles pollution; } \\
\text { High energy } \\
\text { consumption; difficult } \\
\text { to recover precious } \\
\text { metals }\end{array}$ \\
\hline $\begin{array}{l}\text { Mild } \\
\text { extracting } \\
\text { technology }\end{array}$ & Solution & $\begin{array}{l}\text { Almost all metals; } \\
\text { recovery rate related to } \\
\text { the reagents and } \\
\text { reaction condition }\end{array}$ & $\begin{array}{l}\text { Low toxicity; simple } \\
\text { and easy } \\
\text { accessibility; relative } \\
\text { low } \\
\text { environment damage }\end{array}$ & $\begin{array}{l}\text { High cost of some } \\
\text { reagent; } \\
\text { some reagents could } \\
\text { result in } \\
\text { waste water pollution }\end{array}$ \\
\hline $\begin{array}{l}\text { Biometallurg } \\
\text { ical } \\
\text { Technology }\end{array}$ & Solution & $\begin{array}{l}\text { For few specific } \\
\text { metals; } \\
\text { considerable recovery } \\
\text { rate } \\
\text { for } \mathrm{Cu}, \mathrm{Zn}, \mathrm{Au} \text {, etc. }\end{array}$ & $\begin{array}{l}\text { Environment-friendly; } \\
\text { low cost } \\
\text { of investment }\end{array}$ & $\begin{array}{l}\text { For few specific } \\
\text { metals }(\mathrm{Cu}, \mathrm{Zn}, \mathrm{Au}) \\
\text { no industrialization }\end{array}$ \\
\hline $\begin{array}{l}\text { Electrochemi } \\
\text { cal } \\
\text { technology }\end{array}$ & $\begin{array}{l}\text { Pure solid } \\
\text { metals }\end{array}$ & $\begin{array}{l}\text { Only for specific } \\
\text { metals; } \\
\text { high recovery rate }\end{array}$ & $\begin{array}{l}\text { High recovery } \\
\text { efficiency; low } \\
\text { investment; mature } \\
\text { technology }\end{array}$ & $\begin{array}{l}\text { Waste water and } \\
\text { residue } \\
\text { pollution; low } \\
\text { industrialization; }\end{array}$ \\
\hline $\begin{array}{l}\text { Supercritical } \\
\text { technology }\end{array}$ & $\begin{array}{l}\text { Solid } \\
\text { mixture } \\
\text { of metals }\end{array}$ & $\begin{array}{l}\text { Almost all metals; } \\
\text { high } \\
\text { recovery rate }\end{array}$ & $\begin{array}{l}\text { High recovery } \\
\text { efficiency; low } \\
\text { cost of investment; } \\
\text { low } \\
\text { environment damage }\end{array}$ & $\begin{array}{l}\text { Failure to recycle } \\
\text { single metal; } \\
\text { waste oil and waste } \\
\text { gas } \\
\text { pollution; low } \\
\text { industrialization }\end{array}$ \\
\hline $\begin{array}{l}\text { Vacuum } \\
\text { metallurgical } \\
\text { technology }\end{array}$ & $\begin{array}{l}\text { Solid } \\
\text { single } \\
\text { metal }\end{array}$ & $\begin{array}{l}\text { Only for high vapour } \\
\text { pressure metals; high } \\
\text { recovery rate }\end{array}$ & $\begin{array}{l}\text { Environment-friendly; } \\
\text { short } \\
\text { technological process }\end{array}$ & $\begin{array}{l}\text { Relative high cost of } \\
\text { investment; low } \\
\text { industrialization; } \\
\text { immature } \\
\text { technology }\end{array}$ \\
\hline
\end{tabular}




\begin{tabular}{|c|c|c|c|c|}
\hline $\begin{array}{l}\text { Other } \\
\text { metallurgical } \\
\text { technologies } \\
\text { (ultrasonical, } \\
\text { mechanoche } \\
\text { mical } \\
\text { technology) }\end{array}$ & $\begin{array}{l}\text { Solid } \\
\text { mixture } \\
\text { of metals/ } \\
\text { solution }\end{array}$ & $\begin{array}{l}\text { Need to combined } \\
\text { with other } \\
\text { technologies to recycle } \\
\text { metal }\end{array}$ & $\begin{array}{l}\text { Environment-friendly; } \\
\text { low cost } \\
\text { of investment }\end{array}$ & $\begin{array}{l}\text { Failure to recycle } \\
\text { single metal; } \\
\text { no industrialization }\end{array}$ \\
\hline
\end{tabular}

Plastic from WEEE manly consists of thermoplastic copolymers like ABS (Acrylonitrile-Butadiene-Styrene), HIPS (High Impact Polystyrene), PC (Polycarbonate) etc. Separating these plastics is a labor intensive and tedious task. Automated methods like spectroscopic techniques are effective but they are expensive and difficult in handling. Thus, it is beneficial if the entire plastic waste can be treated together. This type of recycling can be achieved using compatabilizers by making a blend. Compatibilization by addition is the most popular technique because of the ease to process. Compatibilizers like SEBS (Styrene-Ethylene-Butylene-Styrene), SBS (Styrene-Butadiene-Styrene) and SBR (Styrene-Butadiene-Rubber) are used for the blends of ABS and HIPS and their selection is based on the similarity of their structure with the plastics. Miscibility of the compatibilizer with the plastic blend is the main factor that is responsible for the choosing them. Through this method, compatibilization blend can be obtained with double ultimate strength and modulus with regards to the physical blend. This technique also improves the mechanical properties of initial plastic waste [20].

\section{Discussion}

Though, extensive research has been carried out on the recycling of individual components of a solar PV system, a research on the whole PV off-grid system recycling is needed. In this study, a sustainable recycling model for solar PV off-grid systems was developed. The model creation was based on the selection of most environmentally friendly and economically feasible recycling practices for the individual components of the system. Fig1. shows the schematic view of sustainable recycling technologies for PV off-grid system.

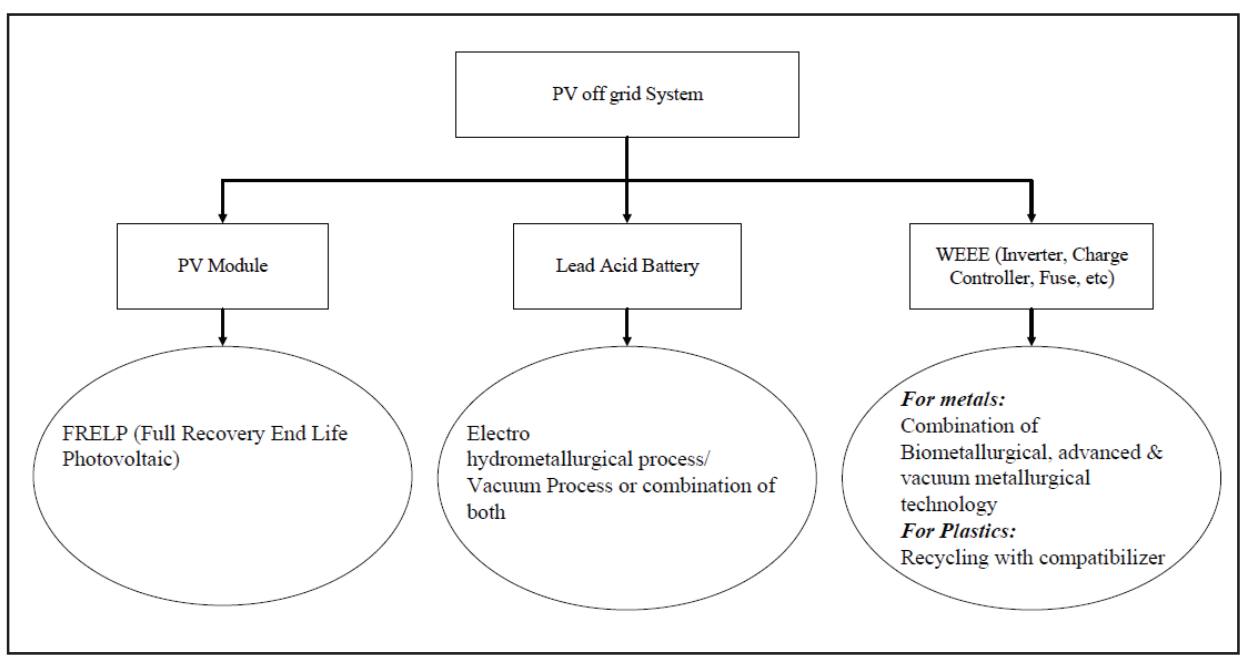


Fig. 1. Sustainable recycling technologies for Solar PV off-grid systems

For PV module, FRELP is considered as the most sustainable recycling technique from the available recycling methods. Latunussa et al. performed Life Cycle Assessment (LCA) method to analyze impacts of recycling of silicon PV modules with FRELP method. LCA analysis focuses mainly sub processes such as transport of the PV waste to the site, the incineration processes, and the further metal recovery from the bottom ash. Result of LCA study on FRELP method states that this method causes less environmental impact with considerable reduction of energy consumption and low CO2 emissions. FRELP process targets full recovery of entire solar panel component materials and their exploitation for Re-use. Up to $98 \%$ by weight of components of solar panel can be converted into salable product [24]. In case of lead acid batteries, Electrohydrometallurgical process \& Vacuum technologies offer better recycling techniques than the traditional Pyrometallurgical process due to reduced emissions and higher lead recovery rates. However, there are still constraints in the electro-hydrometallurgical process which includes additional costs for the chemicals used for electrolytes and deterioration of anodes in electrowinning process. On the other side, vacuum technologies offer more opportunities to avoid metal loss, environmentally cleaner technology with less emissions and consuming less energy for the processing of lead acid batteries. The choice of technology also depends on the other components of the PV off-grid system components like WEEE elements for recycling, where the plastic components from the lead acid battery can be combined with the plastic waste of WEEE. For WEEE, Biometallurgical technology, vacuum metallurgical technology and advanced metallurgical technologies (ultrasonical, mechanochemical technology) provide the right solutions for environmentally friendly recycling with a considerable recovery rate of the material. However, these technologies are either material selective or can recover metals with high vapour pressure or needs to be combined with other recycling technologies. On the positive side, these technologies have a low investment cost except for vacuum metallurgical technology, thus should be encouraged to be easily industrialized and refined. Since WEEE is an extremely complicated system, it is difficult for a single technology to provide all the solutions. Use of compatibilzers like SEBS, SBS, and SBR offer tremendous opportunities to avoid large plastic waste handling and improve the initial material properties. These technologies will be further developed hence combining these technologies to complement each other provides a good sustainable option for recycling in the future. 


\section{Conclusion}

The environmental effects of fossil fuels have led the governments all over the world to change their policies to integrate renewable energies in the energy mix. Climate change is real, so more and more people are opting for solar energy as a means of sustainable electricity supply. This has resulted to a great increase in the number of PV off-grid systems being sold and this trend will continue in the future so long as the technology becomes cheaper, more efficient and easily available. The first generation of PV off -grid systems are at an end of their life span. They will generate a lot of waste and such waste streams will only increase in the future. Traditional methods of recycling e-waste do not provide all the answers to solve this growing problem. These methods are energy intensive, expensive, inefficient and create environmental and health hazards. Current and future recycling technologies for PV off-grid systems are presented in this review. PV off-grid systems are complicated and contain a lot of different parts. For solar modules, through FRELP 95\% of silicon can be recovered and $98 \%$ by weight of components can be converted into products that can be sold. LAB recycling through Electro-hydrometallurgical process \& Vacuum technologies offer eco-friendly recycling methods with excellent recovery rates like 98\% lead recovery. Technologies like vacuum metallurgical technology, ultrasonical technology offer great metal recovery solutions from WEEE and can be industrialized if nurtured properly. All these advanced technologies when used in combination with each other provide sustainable recycling methods for growing PV-off grid systems waste. It is important to continuously research on these technologies to further improve their efficiencies and reduce cost so that they can be successfully realized in the future. More work should be done on ways of smoothly integrating these technologies with each other. Thus, it can be said that future recycling technologies for PV off-grid systems will meet the environmental, economic and social needs successfully.

\section{References}

[1] IRENA, IEA-PVPS (2016): End-of-life management solar photovoltaic panels. International Renewable Energy Agency and the International Energy Agency Photovoltaic Power Systems (ISBN 978-92-95111-99-8). Available online at http://www.irena.org/DocumentDownloads/Publications/IRENA IEAPVPS End-ofLife Solar PV Panels 2016.pdf. 
[2] Kang, Sukmin; Yoo, Sungyeol; Lee, Jina; Boo, Bonghyun; Ryu, Hojin (2012):

Experimental investigations for recycling of silicon and glass from waste photovoltaic modules. In Renewable Energy 47, pp. 152-159. DOI: 10.1016/j.renene.2012.04.030.

[3] IRENA (2015): Off-grid renewable energy systems: status and methodological issues. International Renewable Energy Agency. Available online at http://www.irena.org/DocumentDownloads/Publications/IRENA_Offgrid Renewable Systems WP 2015.pdf.

[4] Latunussa, Cynthia E.L.; Ardente, Fulvio; Blengini, Gian Andrea; Mancini, Lucia (2016): Life Cycle Assessment of an innovative recycling process for crystalline silicon photovoltaic panels. In Solar Energy Materials and Solar Cells. DOI: 10.1016/j.solmat.2016.03.020.

[5] Granata, G.; Pagnanelli, F.; Moscardini, E.; Havlik, T.; Toro, L. (2014): Recycling of photovoltaic panels by physical operations. In Solar Energy Materials and Solar Cells 123, pp. 239-248. DOI: 10.1016/j.solmat.2014.01.012.

[6] Klugmann-Radziemska, Ewa; Ostrowski, Piotr (2010): Chemical treatment of crystalline silicon solar cells as a method of recovering pure silicon from photovoltaic modules. In Renewable Energy 35 (8), pp. 1751-1759. DOI: 10.1016/j.renene.2009.11.031.

[7] Ashfaq, Haroon; Hussain, Ikhlaq; Giri, Ajay: Comparative analysis of old, recycled and new PV modules. In Journal of King Saud University - Engineering Sciences. DOI: 10.1016/j.jksues.2014.08.004.

[8] Espinosa, Denise Crocce Romano; Bernardes, Andréa Moura; Tenório, Jorge Alberto Soares (2004): An overview on the current processes for the recycling of batteries. In Journal of Power Sources 135 (1-2), pp. 311-319. DOI: 10.1016/j.jpowsour.2004.03.083.

[9] Jolly, R.; Rhin, C. (1994): Recycling of Materials in Industry The recycling of lead-acid batteries: production of lead and polypropylene. In Resources, Conservation and Recycling 10 (1), pp. 137-143. DOI: 10.1016/0921-3449(94)90046-9.

[10] Blanpain, Bart; Arnout, Sander; Chintinne, Mathias; R. Swinbourne, Douglas (2014): Chapter 8 - Lead Recycling. In : Handbook of Recycling. Boston: Elsevier, pp. 95-111.

[11] Ferracin, Luiz C.; Chácon-Sanhueza, Abel E.; Davoglio, Rogério A.; Rocha, Luis O.; Caffeu, Daniele J.; Fontanetti, Adilson R. et al. (2002): Lead recovery from a typical Brazilian sludge of exhausted lead-acid batteries using an electrohydrometallurgical process. In Hydrometallurgy 65 (2-3), pp. 137-144. DOI: 10.1016/S0304386X(02)00087-7. 
[12] Lin, Deqiang; Qiu, Keqiang (2011): Recycling of waste lead storage battery by vacuum methods. In Waste Management 31 (7), pp. 1547-1552. DOI: 10.1016/j.wasman.2011.02.019.

[13] Zhang, Wei; Yang, Jiakuan; Wu, Xu; Hu, Yuchen; Yu, Wenhao; Wang, Junxiong et al. (2016): A critical review on secondary lead recycling technology and its prospect. In Renewable and Sustainable Energy Reviews 61, pp. 108-122. DOI:

10.1016/j.rser.2016.03.046.

[14] Zhang, Jing; Chen, Chuanmin; Zhang, Xueying; Liu, Songtao (2016): Study on the Environmental Risk Assessment of Lead-Acid Batteries. In Selected Proceedings of the Tenth International Conference on Waste Management and Technology 31, pp. 873-879. DOI: 10.1016/j.proenv.2016.02.103.

[15] Zabaniotou, A.; Kouskoumvekaki, E.; Sanopoulos, D. (1999): Recycling of spent lead/acid batteries: the case of Greece. In Resources, Conservation and Recycling 25 (34), pp. 301-317. DOI: 10.1016/S0921-3449(98)00071-8.

[16] Widmer, Rolf; Oswald-Krapf, Heidi; Sinha-Khetriwal, Deepali; Schnellmann, Max; Böni, Heinz (2005): Global perspectives on e-waste. In Environmental and Social Impacts of Electronic Waste Recycling 25 (5), pp. 436-458. DOI: 10.1016/j.eiar.2005.04.001.

[17] Ongondo, F. O.; Williams, I. D.; Cherrett, T. J. (2011): How are WEEE doing? A global review of the management of electrical and electronic wastes. In Waste Management 31 (4), pp. 714-730. DOI: 10.1016/j.wasman.2010.10.023.

[18] Zhang, Lingen; Xu, Zhenming (2016): A review of current progress of recycling technologies for metals from waste electrical and electronic equipment. In Journal of Cleaner Production 127, pp. 19-36. DOI: 10.1016/j.jclepro.2016.04.

[19] Makenji, K.; Savage, M. (2012): 10 - Mechanical methods of recycling plastics from WEEE. In : Waste Electrical and Electronic Equipment (WEEE) Handbook : Woodhead Publishing Series in Electronic and Optical Materials: Woodhead Publishing, pp. 212-238.

[20] Vazquez, Yamila V.; Barbosa, Silvia E. (2016): Recycling of mixed plastic waste from electrical and electronic equipment. Added value by compatibilization. In Waste Management 53, pp. 196-203. DOI: 10.1016/j.wasman.2016.04.022.004.

[21] Chi, Xinwen; Streicher-Porte, Martin; Wang, Mark Y.L.; Reuter, Markus A. (2011): Informal electronic waste recycling: A sector review with special focus on China. In Waste Management 31 (4), pp. 731-742. DOI: 10.1016/j.wasman.2010.11.006.

[22] Huang, Chun-Li; Bao, Lian-Jun; Luo, Pei; Wang, Zhao-Yi; Li, Shao-Meng; Zeng, Eddy Y. (2016): Potential health risk for residents around a typical e-waste recycling zone via 
inhalation of size-fractionated particle-bound heavy metals. In Journal of Hazardous Materials 317, pp. 449-456. DOI: 10.1016/j.jhazmat.2016.05.081.

[23] BCI (2016): How a Lead Battery is Recycled. Battery Council International. Available online at http://batterycouncil.org/?page=Battery_Recycling.

[24] SASIL (2010): FRELP Project. SASIL. Available online at http://www.sasillife.com/index.php?option=com_content\&view=article\&id=85\&Itemid=83\&lang=en. 